\title{
Health-Seeking Behavior of Rural Women with Hypertension to Control Blood Pressure in Purwakarta and Padang Pariaman District
}

\author{
Nunung Cipta Dainy', Purnawati Hustina Rahman², Ali Khomsan², Ikeu Tanziha', \\ Naufal Muharam Nurdin ${ }^{2}$, Kasmita ${ }^{3}$
}

1) Nutrition Study Program, Faculty of Medicine and Health, Universitas Muhammadiyah Jakarta, Indonesia
2) Department of Community Nutrition, Faculty of Human Ecology, IPB University, Indonesia
3) Hotel Management Study Program, Faculty of Tourism and Hotels, Universitas Negeri Padang, Indonesia

*Corresponding author: nciptadainy@umj.ac.id

\begin{abstract}
Background: The prevalence of hypertension in West Java and West Sumatra are in high level. Hypertension in rural areas tends to be higher than in urban areas, and women are higher than men. The lack of control of blood pressure in people with hypertension and the delay in seeking treatment can increase mortality. Purposes: This study aims to analyze the women's access to health facilities and health-seeking behavior carried out by women in rural areas. Methods: This study was a cross-sectional method in Purwakarta (Sunda) and Padang Pariaman (Minang) District. There are 75 people each sample women aged 35-55 years with hypertension. Analysis statistic using Pearson Chi-Square. Results: The results show that above $60 \%$ of responden chosen Puskesmas became health facilities. Sunda women significantly use doctor's clinics more than Minang women (p-value <0.05). Most Sunda women changed their behavior by taking antihypertensive drugs and losing weight to controlling blood pressure compared to Minang women ( $\mathrm{p}<0.05$ ). Conclusion: The conclusion, Puskesmas as a main place for treatment and medical-related to control their blood pressure. However, changes in the health behavior of Sunda women prefer to take drugs, and weight loss, while the Minang women tend to reduce salt consumption.
\end{abstract}

Keywords: health-seeking behavior, hypertension, minang, sunda, women

\section{INTRODUCTION}

Globally, cardiovascular disease causes approximately 17.9 million deaths in 2019. Hypertension is a risk factor for CVD (1). In 2019, the global level 2 risk factor for death was high systolic blood pressure, which accounted for up to 10.8 million deaths (19.2\%) (2). The Global Disparities of Hypertension (2016) report that in the period 2000-2010, there was a $2.6 \%$ decrease in the prevalence of hypertension in high-income countries, but an increase of $7.7 \%$ in low-income countries. A report from the NCD Risk Factor Collaboration (NCD-RisC) shows that the number of people aged 30-79 years with hypertension has doubled from 1990 to 2019 and the number of women with hypertension is more than that of men (3).

In Indonesia, according to Riskesdas (2013 \& 2018) $(4,5)$, the prevalence of hypertension has increased. In 2013 the national prevalence of hypertension was $25.8 \%$ with the highest number being $29.4 \%$, while in 2018 the national prevalence of hypertension was $34.1 \%$, 
with the highest figure reaching 44.1\%.This pattern occurs in urban and rural areas, especially in women, where the risk of suffering from hypertension is higher than in men.

Research on adults in rural Indonesia shows that the prevalence of the metabolic syndrome is higher in women (6). This finding is different from the pattern of PTM spread in developed countries, where the risk of developing NCDs is higher in men (7). Still, the impact of NCDs on women is considered more severe related to social norms and productivity as food providers in the household. Hypertension can occur due to a lack of knowledge, perception, lifestyle, attitudes, and practices.

A woman's access to health facilities can depend on her health beliefs and socioeconomic and demographic background in a physical, social, and psychological context (8). The health system in Indonesia is a combination of modern and traditional medicine. The used type of treatment depends on each individual based on health beliefs, background characteristics, and availability of health facilities. The individual's decision to seek treatment depends on educational and economic status, the degree to which he or she is concerned about the symptoms, the duration of the symptoms, and the communication between partners about the signs. Lack of finance to access health services and considering the symptoms felt is common to be the main factor for not seeking treatment.

Health-seeking behavior (HSB) is personal actions to promote optimal health, recovery, and rehabilitation. Factors that affect HSB are family or community identity, which results from a combination of various personal, experience, and sociocultural factors that vary from individual to individual (9). There are many types of health facilities in Indonesia, ranging from modern to traditional. Various factors such as socio-economic status, gender, access to services and perceived quality of the health service influence HSB behavior (10). Notoatmodjo (2014) states that three factors, namely influence a person's health behavior: Predisposing factors (age, occupation, education, knowledge, and attitudes); Enabling factors (distance to health facilities); and Reinforcing factors (family support and community leaders) (11). Sunda and Minang are major ethnic groups in Indonesia with a high prevalence of hypertension, but these two ethnicities have different cultures. Research comparing health-seeking hypertension between these two ethnicities is still limited, most of which only examine one ethnicity; therefore, this study was conducted.

The objective of this study was to identify the types of health facilities, analyze what kinds of health facilities are most accessed by women with hypertension, and analyze changes in the health behavior of women with hypertension in Sunda and Minang villages as an effort to cure hypertension.

\section{METHODS}

This study used a cross sectional design with a sample of women aged 35-55 years who had hypertension (blood pressure systole more than $140 \mathrm{mmHg}$ and diastolic more than $90 \mathrm{mmHg}$ ) (12). The steps of sampling procedure are in Figure 1. 


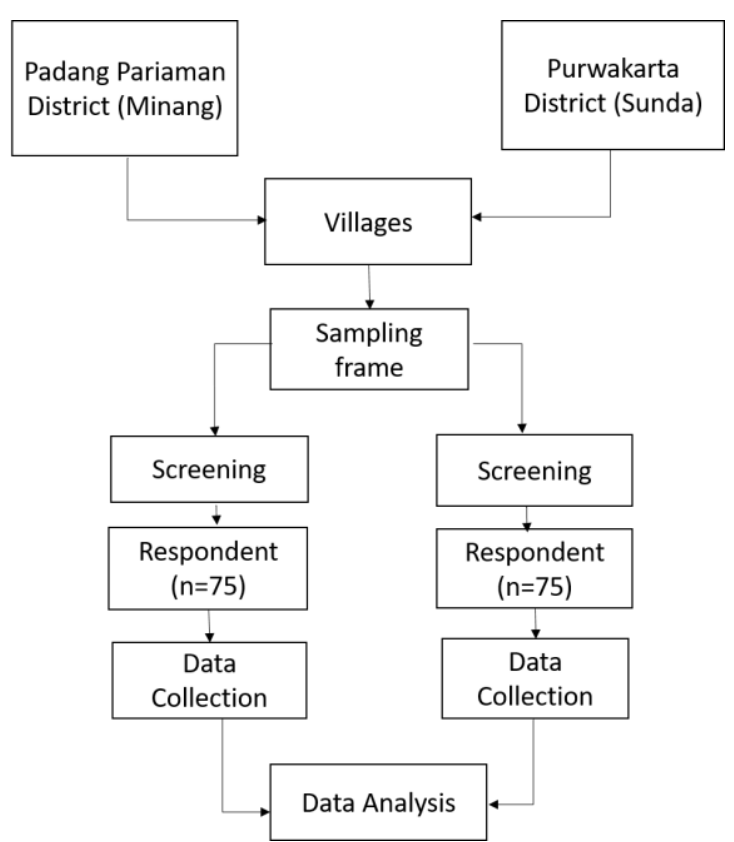

Figure 1. Sampling Procedure in Purwakarta District and Padang Pariaman District

The study used a cross-sectional design in rural women aged 30-55 years who had hypertension, with more than 140/90 $\mathrm{mmHg}$ blood pressure. The study was conducted in two locations with two different ethnicities, namely Pondok Bungur District, Purwakarta Regency, West Java with Sundanese ethnicity and Nan Sabaris District, Padang Pariaman Regency, West Sumatra with Minang ethnicity. Calculation of the number of samples using $80 \%$ power and $5 \%$ alpha obtained a minimum sample size of 75 people/group or a total of 150 people.

The sampling technique used is consecutive sampling. Women are aged 30-55 years who live at the study site participate in socialization and blood pressure checks. Blood pressure measurements were carried out with three repetitions. Women with blood pressure screening results in the category of hypertension were asked to be research subjects.
Data collected by interview using a questionnaire includes demographic data, availability of health facilities, access and choice of health facilities, health-seeking behavior, and types of behavior change. The validity of the research questionnaire has been tested. Statistical analysis using the Pearson Chi-Square test using SPSS software. This research has obtained an ethical license from the Commission of Health Research Ethics Faculty of Public Health University of Diponegoro No. 259/EC/FKM/2017.

\section{RESULT}

The characteristics of the respondents in this study were homogeneous based on age, education, and employment $(\mathrm{P}>0.05)$ (Figure 2).

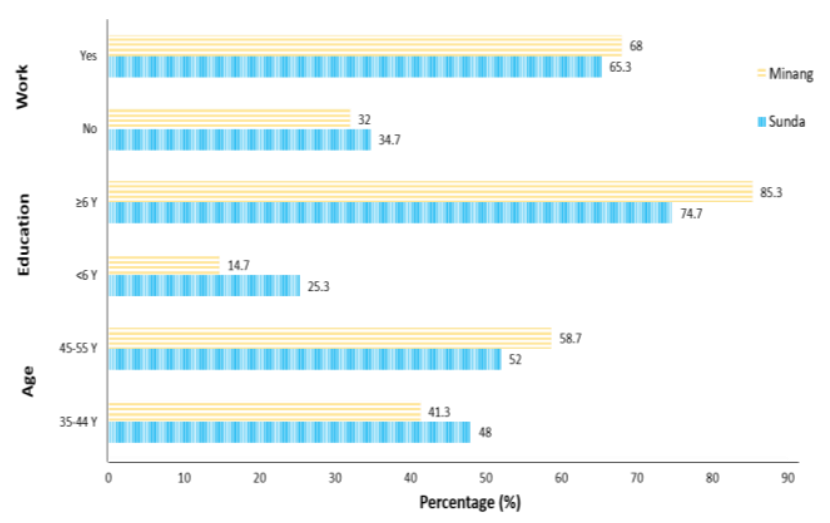

Figure 2. Characteristics of Sunda and Minang women

Health facilities available in these two areas are puskesmas, medical clinics, midwives, posyandu, and traditional medicine. There are significant differences between Sunda and Minang related to Posyandu and traditional clinics ( $p$-value $<0.05)$. The health facilities that are the primary choice of respondents for treatment are puskesmas (Figure 3). 


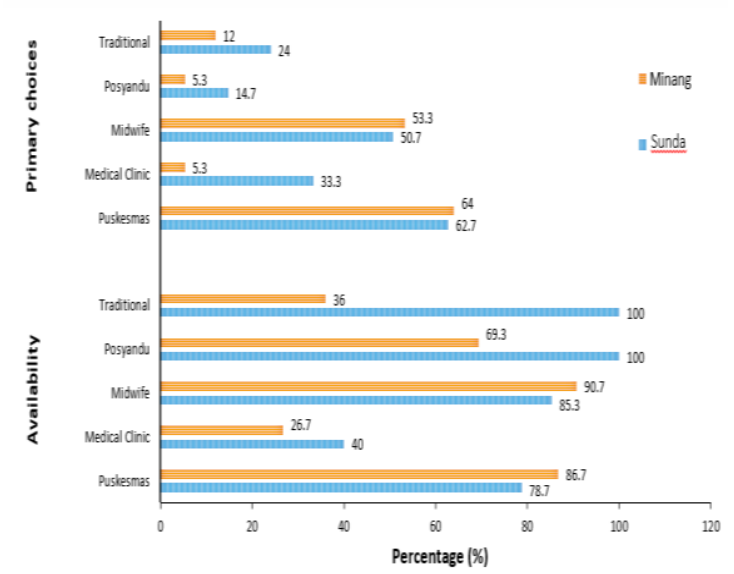

Figure 3. Availability and respondents primary choices of health facilities

There was a significant difference related to the use of the clinic clinic, which was significantly more significant than in Minang ( $\mathrm{p}$-value $<0.05$ ). Behavior changes occur in most respondents in Sunda and Minang, but differ in terms of changes in types of behavior. Figure 4 shows Sunda respondents consume more antihypertensive drugs and lose weight ( $p$-value $<0.05)$ compared to Minang respondents.

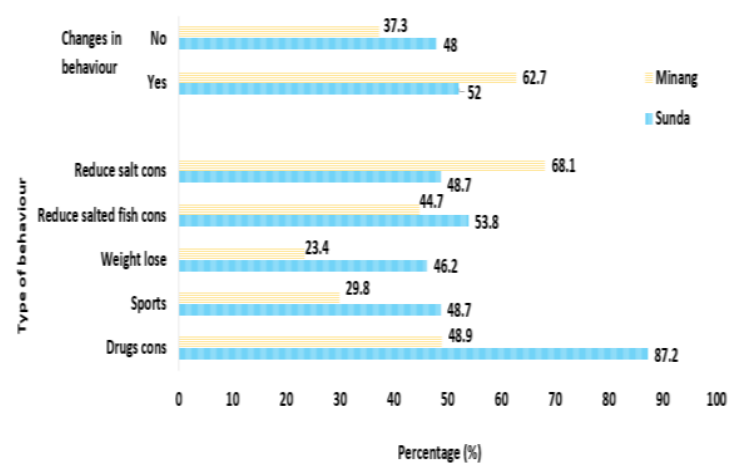

Figure 4. Changes in the behavior of Sunda and Minang women

\section{DISCUSSION}

Differences characteristics between Sunda and Minang women in terms of the number of family members are in line with the data on family planning use. Sunda women mostly use family planning so that most of the Sunda women have a small number of family members ( $\leq 4$ people). The Minang women are less likely to use family planning program so that most of their family members are large families (> 4 people). The family planning program is one of the government programs that has both quantitative and qualitative objectives. The quantitative objective of the family planning program is to reduce and control the rate of population growth, while the qualitative goal is to realize the Norma Keluarga Kecil yang Bahagia dan Sejahtera (NKKBS)(13). Hartoyo et al., (2011) stated that family size has a positive influence on the number of children desired $(14,15)$.

The availability of health facilities is one of the efforts to promote public health. The Ministry of Health (2015) reports that the development of the number of posyandu in Indonesia is good, with the ratio of posyandu to village of 3.51 posyandu (16). The difference in the percentage of posyandu in the Sunda and Minang respondent areas is due to the difference in the number of villages. Sunda respondents came from one village, while Minang respondents came from more than one village. The ideal village has a posyandu in every Rukun Warga (RW), so that in one village the number of posyandu is equal to the number of RWs. However, this is not absolute because it is influenced by the number of residents, the availability of space for posyandu locations, and the number of posyandu cadres.

In addition to the existence of posyandu, the existence of traditional health facilities is also different between Sunda and Minang. In Sunda there are $100 \%$ of traditional health facilities, while in Minang only 36\%. Susanti and Sukaesih (2017) stated that before the development of modern medicine, based on local 
wisdom, Indonesian people used to use plants as medicine (17). This is in accordance with Purnama's research (2016) which states that traditional medicine is one of the local wisdom in West Java due to natural factors that support fertile soil that grows many types of medicinal plants, safety (side effects), low prices, and easy to obtain (18).

Currently, although modern medicinal products have developed, there are still people who still maintain local wisdom by using plants as a treatment. The Sunda people may still maintain this local wisdom more than the Minang people. According to Ferina (2015) health and traditional culture are two related things. People have confidence in themselves and their families based on their culture(19). However, it is necessary to pay attention to the harmony between community groups who have certain cultural beliefs so as not to harm or even endanger health.

Puskesmas is still the main goal of the community to get health in both Sunda and Minang. Puskesmas is a health service facility that organizes public health efforts as well as individual health efforts at the first level. Services at the puskesmas prioritize promotive and preventive efforts. Napiran et al. (2016) stated that the utilization of Puskesmas services was influenced by several factors including public perceptions of health, public perceptions of service quality, education level and access to both economic access (family income), and physical access (mileage) (20).

Changes in health behavior differed between Sunda and Minang respondents. Sunda respondents prefer to take blood pressure-lowering drugs, while Minang respondents prefer to reduce salt consumption. Riskesdas data in 2013 showed that patients with hypertension in Indonesia reached $25.8 \%$ but controlling blood pressure of people with hypertension could not be fully controlled even though medicines were already available. Controlling the blood pressure of people with hypertension can be done one of them by maintaining a diet, doing daily activities and taking hypertension drugs $(21,22)$.

The limitation of this study is data collection in the two areas was not carried out simultaneously because the researchers were involved and went directly to the field during the data collection process in both regions and made sure the data obtained was accurate. Although data collection is conducted at different times, it is still arranged in the same season. Therefore, it does not affect the healthseeking behavior of the subject.

\section{CONCLUSION}

Health facilities that available and accessible in Purwakarta and Padang Pariaman are health centers (Puskesmas), medical clinics, midwives, Posyandu and traditional medicine. Health facilities that the main choices are Puskesmas. The health seeking behavior of Sunda women is to take antihypertensive drugs and lose weight, while Minang women tend to reduce salt intake.

The implication of this study is necessary for different strategies in dealing with hypertension in the two regions. For example, Sunda women are given education about the wise use of traditional medicine. On the other hand, Minang women were given education about the modification of low-salt food processing. 


\section{ACKNOWLEDGMENT}

We would like to especially thank the Neys - van Hoogstraten Foundation, for financial support in conducting this study with the grant number IN296. The authors have no conflict of internests.

\section{CONFLICT OF INTEREST}

Authors have no conflict of interest, and no affiliation or connection to or with any entity or organization.

\section{REFERENCE}

1. WHO. Cardiovascular diseases (CVDs). 2021.

2. Metrics GH. Global burden of 87 risk factors in 204 countries and territories , $1990-2019$ : a systematic analysis for the Global Burden of Disease Study 2019. 2020;1223-49.

3. Zhou B, Carrillo-Larco RM, Danaei G, Riley LM, Paciorek CJ, Stevens $\mathrm{GA}$, et al. Worldwide trends in hypertension prevalence and progress in treatment and control from 1990 to 2019: a pooled analysis of 1201 populationrepresentative studies with 104 million participants. Lancet. 2021;398(10304):957-80.

4. Kementerian Kesehatan Republik Indonesia. Laporan Nasional Riset Kesehatan Dasar (Riskesdas) 2013. Jakarta; 2013.

5. Badan Penelitian dan Pengembangan Kesehatan. Riset Kesehatan Dasar (RISKESDAS) 2013. Lap Nas 2013. 2013;1-384.

6. Nurdin NM, Anwar F, Riyadi H DR.

Socio-Economic, Demographic, Dietary And Lifestyle Characteristic And The Prevalence Of Metabolic Syndrome
Of Middle Aged Rural People. 2015.

7. Song Q Bin, Zhao Y, Liu YQ, Zhang J, Xin SJ, Dong GH. Sex difference in the prevalence of metabolic syndrome and cardiovascular-related risk factors in urban adults from 33 communities of China: The CHPSNE study. Diabetes Vasc Dis Res. 2015;12(3):189-98.

8. Das A. Health Seeking Behavior of Women with Hypertension and their Control of Blood Pressure: A NonExperimental Approach. IJSR. 2013;4(8):1922-6.

9. Mushtaq $\mathrm{K}$, Hussain $\mathrm{M}$, et al. Factors Affecting Health Seeking Behavior and Health Services in Pakistan. Natl J Heal Sci. 2020;5(1):30-4.

10. Latunji OO, Akinyemi OO. Factors Influencing Health-Seeking Behaviour Among Civil Servants in Ibadan, Nigeria. Ann Ibadan Postgrad Med. 2018;16(1):52-60.

11. Notoatmodjo S. Ilmu Perilaku Kesehatan. Jakarta: Rineka Cipta; 2014.

12. American Academy of Family Physicians. C. JNC 8 Guidelines for The Management of Hypertension in Adult. Am Fam Physician. 2014;90(7):503-4.

13. BKKBN. Peran bkkbn di balik gerakan penanggulangan Stunting. 2018;1-44.

14. Oktriyanto, H.Puspitawati IM. The Value and Preferred Number of Children among Eligible Couples in Rural and Urban Areas Abstract. Jur Ilm Kel Kons. 2015;8(1):1-9.

15. Buhr $P$, Lutz $K$, Peter T. The influence of the number of siblings 
on expected family size in a cohort of young adults in Germany. Demogr Res. 2018;39(1):315-36.

16. Kemenkes RI. Profil Kesehatan Indonesia Tahun 2014. Jakarta; 2015.

17. Susanti S dan Sukaesih. Kearifan Lokal Sunda Dalam Pemanfaatan Tanaman Berkhasiat Obat Oleh Masyarakat Cipatat Kabupaten Bandung Barat. WACANA. 2017;16(2):291 - 298.

18. Purnama Y. Kearifan lokal masyarakat jatigede dalam pengobatan tradisional. 2016;

19. Ferina. Antropologi Kesehatan Pada Budaya Sunda. Universitas Padjajaran. Bandung.; 2015.
20. Napirah MR, Rahman A TA. Faktor-Faktor Yang Berhubungan Dengan Pemanfaatan Pelayanan Kesehatan Di Wilayah Kerja Puskesmas Tambarana Kecamatan Poso Pesisir Utara Kabupaten Poso. J Pengemb Kota. 2016;4(1):29-39.

21. Kiha RR, Palimbong S KM. Keefektifan Diet Rendah Garam I Pada Makanan Biasa Dan Lunak Terhadap Lama Kesembuhan Pasien Hipertensi. J Keperawatan Muhammadiyah. 2018;3(1):76-89.

22. Bazzano LA, Green T, Harrison TN, Reynolds K. Dietary approaches to prevent hypertension. Curr Hypertens Rep. 2013;15(6):694702. 